\title{
Sex cord-stromal tumor with annular tubules of the ovary - a case report
}

\author{
Lakshmanrao Gaikwad S. ${ }^{1}$, Dhanlal Sathawane R. ${ }^{2 *}$, Ulhas Naragude P. ${ }^{3}$, Namdeorao Bagate A. ${ }^{4}$ \\ DOI: https://doi.org/10.17511/jopm.2020.i07.07 \\ ${ }^{1}$ Sheela Lakshmanrao Gaikwad, Associate Professor, Department of Pathology, S.R.T.R. Govt. Medical College, Beed, Maharashtra, India. \\ 2* Rama Dhanlal Sathawane, Junior Resident, Department of Pathology, S.R.T.R. Govt. Medical College, Beed, Maharashtra, India. \\ 3 Piyusha Ulhas Naragude, Assistant Professor, Department of Pathology, S.R.T.R. Govt. Medical College, Beed, Maharashtra, India. \\ ${ }^{4}$ Arvind Namdeorao Bagate, Head of the Department, Department of Pathology, S.R.T.R. Govt. Medical College, Beed, Maharashtra, India.
}

Sex cord-stromal tumors with annular tubules (SCTAT) of the ovary are rare. They have two clinical presentation forms: the syndromic form which is associated with Peutz-Jeghers syndrome and the non-syndromic form which is frequently seen in the second or third decades. We describe a 25-yearold patient who underwent exploratory laparotomy. Macroscopically large ovarian mass was $24.5 \times 24 \times 8 \mathrm{~cm}$ in diameter, encapsulated, congested, and lobulated. On the cut section, it was greyish with small cystic and hemorrhagic areas. Microscopically, the tumor mass is composed of many simple and complex tubular structures that have eosinophilic PAS-positive hyaline globules in the center and are surrounded by peripheral palisading of the cells. Finally, the tumor was diagnosed as non-syndromic ovarian SCTAT.

Keywords: Ovary, Ovarian tumor, Sex cord-stromal tumor, SCTAT

\section{Corresponding Author}

Rama Dhanlal Sathawane, Junior Resident, Department of Pathology, S.R.T.R. Govt. Medical College, Beed, Maharashtra, India.

Email: ramasprov@gmail.com

\section{How to Cite this Article}

Gaikwad SL, Sathawane RD, Naragude PU, Bagate AN. Sex cord-stromal tumor with annular tubules of the ovary - a case report. Trop J Pathol Microbiol. 2020;6(7):455-458.

Available From

https://pathology.medresearch.in/index.php/jopm/ar ticle/view/489
To Browse

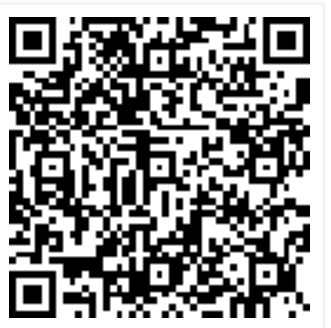

Manuscript Received 2020-10-17

Conflict of Interest No
Review Round 1 2020-10-25

Funding

$\mathrm{Nil}$
Review Round 2

2020-10-27

Ethical Approval Yres
Review Round 3

Plagiarism X-checker $7 \%$
Accepted 2020-10-29

Note

() 2020 by Sheela Lakshmanrao Gaikwad, Rama Dhanlal Sathawane, Piyusha Ulhas Naragude, Arvind Namdeorao Bagate and Published by Siddharth Health Research and Social Welfare Society. This is an Open Access article licensed under a Creative Commons Attribution 4.0 International License https://creativecommons.org/licenses/by/4.0/ unported [CC BY 4.0].

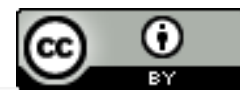




\section{Introduction}

Sex cord-stromal tumors of the ovary account for only $5 \%$ of all ovarian neoplasms and sex cordstromal tumors with annular tubules (SCTAT) are very rare tumors in this group. Many of these tumors are clinically indolent, so a long period of follow-up is required to precisely clarify outcomes data. Sex cord-stromal tumors with annular tubules have two clinical presentation forms: one-third of the tumors are associated with Peutz-Jeghers syndrome, and the other form occurs as solitary neoplasm in the general population [1,2]. In patients with Peutz-Jeghers syndrome, the tumors are usually bilateral, multifocal, and almost always very small tumors found incidentally in the ovaries; all of them are clinically benign $[1,2]$. There is some calcification in the tumoral tissues. The syndromic form can be seen in all age groups, and the mean age is 27 years. Also, nearly $15 \%$ of patients with Peutz-Jeghers syndrome may have cervical adenocarcinoma [3-5]. The second one is the nonsyndromic form, which is not associated with PeutzJeghers syndrome as in this case report. They are usually unilateral, unifocal, and larger than $3 \mathrm{~cm}$, and sometimes behave in a malignant manner (up to $1 / 5$ of patients) with lethal metastases or recurrences. The mean age is 34 years $[1,2]$. Serum inhibin, Mullerian inhibitory substance, and progesterone can be used as tumor markers for SCTATs. Also, nearly half of the tumors from the latter group have manifested clinical signs of hyperestrogenism and hyperprogesteronism [1,2]. Therefore, SCTAT can present with precocious puberty, menstrual disorder, or postmenopausal vaginal bleeding, depending on presentation age. The histopathological features of SCTAT cases are identical for both syndromic and non-syndromic forms. Most authors have suggested that these tumors are related to granulosa cell tumors and partly Sertoli cell tumors, but actually, these tumors have histological features of both cell types. In brief, SCTATs are accepted as an intermediate category $[1,2]$.

\section{Case Report}

The patient was a 25-year-old, P2L2 multiparous woman and was admitted for nine months of amenorrhoea, mass in abdo-pelvis with pain in the abdomen. As per the Abdo examination, the uterus was 26 weeks. Abdominal ultrasonography showed a right-sided ovarian mass. Exploratory laparotomy was done to excise this mass.
Macroscopically, the removed ovarian mass was $24.5 \times 24 \times 8 \mathrm{~cm}$, encapsulated by a fibrous capsule, lobulated, congested. Cut surface is greyish, firm in consistency, few necrotic, and cystic areas noted (Figure1). Microscopically, the tumor mass is composed of many simple and complex tubular structures that have eosinophilic PAS-positive hyaline material in the center and surrounded by peripheral palisading of the cells.

The individual tumor cells have small single nuclei and wide pale cytoplasm with occasional mitosis. Areas of necrosis are also evident (Figure2 and Figure 3). In the light of all these findings, the tumor was diagnosed as SCTAT of the ovary.

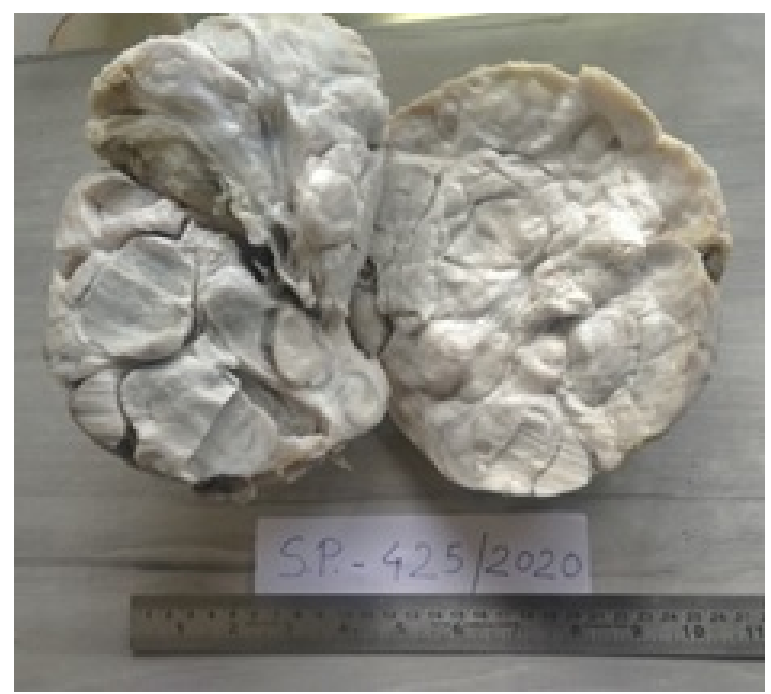

Fig-1: Gross: Ovarian mass is greyish, encapsulated, lobulated with necrotic and cystic areas.

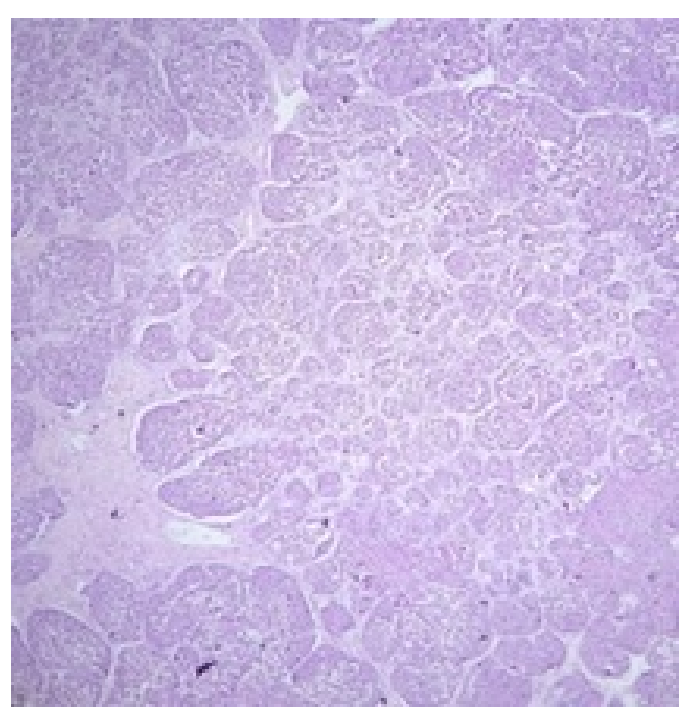

Fig-2: (H\&E)(10X) Tumor mass composed of a simple and complex tubular structure hyaline material in the center. 


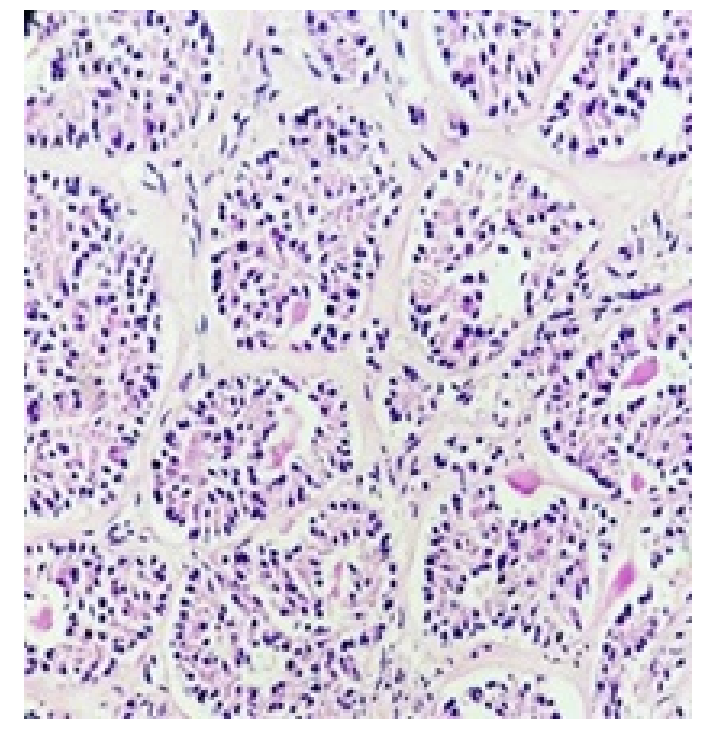

Fig-3: (H\&E) (40X) PAS-positive hyaline material with peripheral palisading of cells.

\section{Discussion}

Sex cord-stromal tumors with annular tubules are rare ovarian neoplasms that can occur in two different clinical settings. One of them is described in patients with Peutz-Jeghers syndrome. The other is named as non-syndromic or sporadic form $[1,2]$.

Our case was of a non-syndromic SCTAT. Nonsyndromic SCTATs were not seen frequently in the multiparous (G2P2L2). Most of the tumors were diagnosed when the patients were in their second or third decades.

The mean age is 34 years. The presented case was 25 years old. The non-syndromic SCTATs are usually unilateral, unifocal, and larger than $3 \mathrm{~cm}$ and sometimes behave in a malignant manner (in up to $1 / 5$ of patients) with lethal metastases or recurrences. The tumor size in our patient was also considerably big. The tumor sizes of previously reported cases have ranged from 5 to $30 \mathrm{~cm}$ in diameter [6-9].

Most authors have suggested that the SCTATs are related to granulosa cell tumors and partly Sertoli cell tumors. SCTATs have histological features of both cell types $[1,2]$. Therefore, SCTATs must be distinguished from microfollicular granulosa cell tumors, well-differentiated Sertoli cell tumors, as well as gonadoblastomas.

\section{Conclusion}

Sex cord-stromal tumors with annular tubule is a rarely determined entity of the ovary.
To add a case to medical literature, we wanted to present our case who was a multiparous woman.

\section{Reference}

01. Roth LM. Sex-cord stromal tumors of the ovary, In Fox $H$, Wells $M$, Editors. Obstetrical and Gynaecological Pathology. 5th ed, Churchill Livigstone. 2003;p-745-70 [Crossref]

02. Russel P, Robboy SJ, Prat J. Sex-cord stromal and steroid cell tumors of the ovaries, In Robboy SJ, Mutter GL, Prat J, Bentley RC, Russel $\mathrm{P}$, Anderson MC, Editors. Pathology of the Female Reproductive Tract. 2nd ed, Churchill Livigstone.

2009;p-693-727 [Crossref]

03. Srivatsa PJ, Keeney GL, Podratz KC. Disseminated cervical adenoma malignum and bilateral ovarian sex-cord tumors with annuler tubules with Peutz Jeghers syndrome. Gynecol Oncol. 1994;53(2)256-264.

doi: 10.1006/gyno.1994.1127 [Crossref]

04. Ayadi-Kaddour A, Bouraoui S, Bellil K, Bellil S, Kchir N, Zitouna MM, et al. Colonic adenocarcinoma and bilateral malignant ovarian sex cord tumor with annular tubules in PeutzJeghers syndrome. Pathologica. 2004;96(3)117120.

[Crossref]

05. Mangili G, Taccagni G, Garavaglia E, Carnelli M, Montoli S. An unusual admixture of neoplastic and metaplastic lesions of the female genital tract in the Peutz Jeghers syndrome. Gynecol Oncol. 2004;92(1)337-342.

doi: $\quad 10.1016 /$ j.ygyno.2003.10.005 [Crossref]

06. Shen K, Wu PC, Lang JH, Huang RL, Tang MT, Lian LJ. Ovarian sex-cord tumor with annular tubules. A report of six cases. Gynecol Oncol. 1993;48(2)180-184. doi: 10.1006/gyno.1993.1030 [Crossref]

07. Moon WS, Lee DG. Ovarian sex-cord tumor with annuler tubules in a patient with Turner syndrome. J Korean Med Sci. 1998;13(1)89-94. doi: $10.3346 / \mathrm{jkms} .1998 .13 .1 .89$ [Crossref] 
08. Galiana SG, Monteagudo C, Tortajada M, Llombart A, Cano A. Ovarian sex cord tumor with annular tubules in a woman with premature ovarian failure. Fertil and Steril. 2001;76(6) 1264-1266.

doi: $\quad 10.1016 / s 0015-0282(01) 02907-7 \quad$ [Crossref]
09. Hirschman SA, Dottino P, Deligdisch L, Szporn A. Cytology of Sexcord tumor with annuler tubules- a cese report. Diagn Cytopathol. $1998 ; 18(5) 362-364$.

doi:

$10.1002 /$ (sici)1097-

0339(199805)18:5<362: :aid-dc12>3.0.c0;2-g [Crossref] 